Indonesian Journal of
Health Community
http://e-journal.ivet.ac.id/index.php/ijheco

\title{
Faktor-Faktor yang Berhubungan dengan Kesembuhan Tuberkulosis pada Penderita Tuberkulosis di Kota Semarang
}

\author{
Nabila Nida Chusna ${ }^{\bowtie 1}$, Lukman Fauzi $^{1}$ \\ ${ }^{1}$ Jurusan Ilmu Kesehatan Masyarakat, Fakultas Ilmu Keolahragaan, Universitas Negeri Semarang, \\ Indonesia
}

DOI: $\underline{\text { https: / /doi.org/10.31331/ijheco.v2i1.1625 }}$

\begin{abstract}
Info Articles
Sejarah Artikel:

Disubmit 1 Mei 2021

Direvisi 27 Mei 2021

Disetujui 7 Juni 2021

Keywords:

Mycobacterium Tuberculosis;

Tuberculosis cure, case control

Abstrak

Tuberkulosis (TB) adalah penyakit menular langsung yang disebabkan oleh bakteri TB yang bernama Mycobacterium Tuberculosis. Orang dengan TB aktif dapat menginfeksi 5-15 orang lain melalui kontak dekat selama setahun. Data Dinas Kesehatan Kota Semarang tahun 2019 menunjukan bahwa masih banyak kasus TB di Kota Semarang yaitu 43,38\%. Data Puskesmas Halmahera Kota Semarang menunjukkan bahwa pada tahun 2019 pasien TB paru yang sembuh sebanyak 38\%, Puskesmas Bangetayu sebanyak 57\%, dan di Puskesmas Genuk sebanyak 43\%. Tujuan penelitian ini adalah untuk mengetahui faktor-faktor yang berhubungan dengan kesembuhan tuberkulosis pada penderita tuberkulosis di Kota Semarang. Jenis penelitian ini merupakan penelitian observasional dengan rancangan case control dengan teknik two stage cluster sampling. Sampel penelitian sebesar 38 responden kasus dan 38 responden kontrol. Instrumen penelitian menggunakan kuesioner, alat antropometri (timbangan injak dan microtoice), serta lembar food frequency questioner (ffq). Analisis data penelitian dianalisis menggunakan uji deskriptif, uji Chi Square, dan regresi logistik. Hasil penelitian menunjukan bahwa ada hubungan antara riwayat asupan vitamin $\mathrm{A}(\mathrm{p}=0,002)$, riwayat asupan vitamin $\mathrm{D}$ $(\mathrm{p}=0,005)$, dan kepatuhan minum obat $(\mathrm{p}=0,001)$ dengan kesembuhan tuberkulosis.
\end{abstract}

\begin{abstract}
Tuberculosis (TB) is a direct infectious disease caused by the TB bacteria called Mycobacterium Tuberculosis. People with active TB can infect another 5-15 people through close contact during the year. Semarang City Health Office data in 2019 showed that there was still many TB incidence case in Semarang, was around 43.38\%. Data from the Halmahera Primary Healthcare Center in Semarang showed that in 2019 there were 38\% of pulmonary TB patients who recovered, Bangetayu there were $57 \%$, and Genuk were $43 \%$. The purpose of studied was to determine the factors associated with tuberculosis cure among tuberculosis patients in Semarang City. This research was observational study with case control design with two stage cluster sampling technique. The sample size consisted of 38 cases and 38 controls. The research instrument used a questionnaire, anthropometric tools (weighing scale and microtoice), and food frequency questionnaire (FFQ) form. Data were analyzed using descriptive test, chi square test, and logistic regression. The results showed that there was a association between history of vitamin A intake $(p=0,002)$, history of vitamin D intake ( $p$ $=0,005)$, and medication adherence $(p=0,001)$ with the cure for $T B$.
\end{abstract}

\footnotetext{
Alamat Korespondensi: Gedung F5 Lantai 2 FIK Unnes Kampus Sekaran,

Gunungpati, Semarang, 50229
}

E-mail: nabilanida@students.unnes.ac.id
p-ISSN 2721-8503

e-ISSN 2775-9997 


\section{PENDAHULUAN}

Tuberkulosis (TB) adalah penyakit menular langsung yang disebabkan oleh bakteri TB yang bernama Mycobacterium Tuberkulosis. Penyakit TB dapat menyerang di hampir seluruh organ tubuh pada manusia dan tersering adalah organ paru-paru. TB menyebar dari orang ke orang melalui udara. Ketika orang dengan TB paru batuk, bersin atau meludah, maka akan mendorong kuman TB ke udara. Orang yang terinfeksi bakteri TB memiliki risiko 5-15\% seumur hidup terserang TB. Ketika seseorang mengembangkan penyakit TB aktif, gejalanya (seperti batuk, demam, keringat malam, atau penurunan berat badan) mungkin ringan selama berbulan-bulan. Hal ini dapat menyebabkan keterlambatan dalam mencari perawatan, dan mengakibatkan penularan bakteri ke orang lain. Orang dengan TB aktif dapat menginfeksi 5-15 orang lain melalui kontak dekat selama setahun (Kementerian Kesehatan RI, 2018).

Berdasarkan data organisasi kesehatan dunia (World Health Organization/WHO) di Indonesia pada tahun 2019 mencapai 845.000 pengidap TB Paru. Dari jumlah tersebut hanya 445.000 pengidap yang melapor sedangkan sekitar 400.000 pengidap lainnya tidak terdiagnosis karena tidak melapor. Jumlah kejadian TB paru di Indonesia yang ditandai dengan adanya Basil Tahan Asam (BTA) positif pada pasien adalah 110 per 100.000 penduduk (Badan Penelitian dan Pengembangan Kesehatan Kementerian RI, 2013)

Menurut Data Dinas Kesehatan Kota Semarang, menunjukan bahwa angka kesembuhan kasus kejadian TB di Kota Semarang pada tahun 2019 yaitu 43,38\%. Cakupan angka konversi TB Paru BTA positif dalam 5 tahun terakhir (2015-2019) masih berada di bawah target nasional $80 \%$. Penderita yang mengalami kegagalan konversi masih memberi peluang menjadi sumber penularan TB pada anggota keluarga dan masyarakat sekitarnya. Data Puskesmas Halmahera Kota Semarang menunjukkan bahwa pada tahun 2017 hinga tahun 2019 proporsi kesembuhan pasien TB menunjukkan angka yang fluktuatif. Tahun 2017 adalah sebesar 76\%, tahun 2018 adalah sebesar 42\%, dan tahun 2019 adalah sebesar 38\%. Dengan demikian dapat memungkinkan terjadinya penurunan pada tahun berikutnya. Selain itu cure rete tahun 2019 tidak memenuhi target minimal yang ditetapkan nasional (minimal 90\%). Adapun data gagal konversi di Puskesmas Halmahera menyebutkan bahwa pada tahun 2017 hingga tahun 2019 proporsi gagal konversi pasien TB menunjukkan angka fluktuatif. Tahun 2017 adalah sebesar 61\%, tahun 2018 adalah sebesar 64\%, dan tahun 2019 adalah sebesar 60\% (Puskesmas Halmahera Tahun 2016-2019).

Dibandingkan dengan puskesmas lainnya, data kesembuhan Puskesmas Bangetayu dan Puskesmas Genuk pada tahun 2017 hingga tahun 2019 juga mengalami fluktuatif. Puskesmas Bangetayu menunjukkan bahwa pada tahun 2017 adalah sebesar 52\%, tahun 2018 adalah sebesar 51\%, dan tahun 2019 adalah sebesar 57\%. Pada Puskesmas Genuk menunjukkan bahwa pada tahun 2017 adalah sebesar 65\%, tahun 2018 adalah sebesar 61\%, dan tahun 2019 adalah sebesar 43\% (Dinas Kesehatan Kota Semarang 2016-2019).

Adapun data gagal konversi di Puskesmas Bangetayu dan Genuk menunjukkan bahwa pada tahun 2017 adalah sebesar 47\%, tahun 2018 adalah sebesar 48\%, dan tahun 2019 adalah sebesar 49\%. Pada Puskesmas Genuk menunjukkan bahwa pada tahun 2017 adalah sebesar 50\%, tahun 2018 adalah sebesar 55\%, dan tahun 2019 adalah sebesar 50\% (Dinas Kesehatan Kota Semarang 2016-2019).

Menurut Aibana (2019), terdapat dua faktor yang mempengaruhi konversi pada pasien TB paru, yaitu faktor internal dan eksternal. Faktor internal meliputi karakteristik dan perilaku pasien itu sendiri, seperti jenis kelamin, jenis pekerjaan, usia, tingkat pendidikan sedangkan faktor eksternal meliputi faktor lingkungan dan sosial yang berada disekitar pasien, seperti kondisi rumah, kepatuhan minum obat, dan lainlain. Sebelum ditemukan terapi OAT, pemberian nutrisi dianggap menjadi terapi utama melawan TB, sebagai contoh adalah vitamin A dan vitamin D (Aibana dkk, 2019).

Vitamin A diketahui memiliki peran sebagai immunoprotective melawan basil TB paru dan dapat menjadi salah satu immunomodulator yang dapat merupakan salah satu alternatif sebagai asupan pendamping dengan obat-obatan standar anti Tuberkulosis. Vitamin A merupakan vitamin yang larut dalam lemak yang berperan penting dalam imunitas, penglihatan, reproduksi, dan komunikasi seluler (Ross $d k k$, 2014).

Vitamin D memiliki fungsi sama seperti vitamin A dalam sistem imunitas yaitu kemampuan mengaktifasi makrofag. Vitamin D mampu menjadi peningkat sistem imun, sebagai pro-hormon dan memainkan peran penting dalam pengaturan kalsium dan pemeliharaan kadar fosfor dalam darah (Aibana dkk, 2019) Vitamin D dibutuhkan untuk menyerap kalsium di dalam usus dan untuk mendapatkan kembali kalsium yang seharusnya dikeluarkan melalui ginjal. Vitamin D di dalam tubuh sangat dipengaruhi oleh paparan sinar matahari dan asupan makanan yang mengandung vitamin D. Paparan sinar matahari yang berlangsung di pagi hari adalah $80 \%$ sumber alami vitamin D. Kondisi kekurangan vitamin D dalam tubuh menjadi erat kaitannya dengan penyinaran matahari. Kombinasi antara vitamin A dan vitamin D dalam 
jumlah dosis normal sampai dengan rendah dapat meningkatkan efektifitas sistem imun. (Marpaung, Siagian and Sari, 2018).

Berdasarkan uraian diatas, faktor yang berhubungan dengan kesembuhan tuberkulosis pada penderita tuberkulosis dipengaruhi oleh beberapa faktor termasuk dari faktor internal dan eksternal. Oleh karena itu, peneliti tertarik untuk mengidentifikasi faktor apa sajakah yang berhubungan dengan kesembuhan tuberkulosis pada penderita tuberkulosis di Kota Semarang.

\section{METODE}

Penelitian ini merupakan jenis penelitian observasional dengan mnenggunakan pendekatan case control yang dimulai dengan mengidentifikasi kelompok yang terkena penyakit atau akibat tertentu (kasus) dan kelompok yang tidak terkena dampak (kontrol), kemudian ditelusuri riwayat penyebab penyakit atau akibatnya ditelusuri riwayat sebelumnya. Populasi dalam penelitian ini adalah penderita TB tahap pengobatan intensif di Puskesmas Halmahera, Bangetayu, dan Genuk Kota Semarang bulan Juli 2020. Besar sampel sebanyak 38 orang (penderita gagal konversi) dan 38 orang (penderita konversi). Pengambilan sampel dalam penelitian ini menggunakan cluster sampling dua tahap dari anggota populasi di puskesmas Kota Semarang. Pengambilan sampel dari 43 Puskesmas di Kota Semarang akan di ambil 3 puskesmas dengan angka gagal konversi tertinggi dan angka kesembuhan terendah di Kota Semarang. Pengumpulan data sekunder dilakukan untuk mengetahui gagal konversi dan konversi pada penderita tuberkulosis paru yang sudah menjalani pengobatan fase intensif.

Variabel dalam penelitian ini adalah riwayat asupan vitamin A, riwayat asupan vitamin D, kepatuhan minum obat, perilaku merokok, status gizi, umur, jenis kelamin, jenis pekerjaan, dan tingkat pendidikan. Protokol penelitian telah disetujui oleh pengurus dewan etik kelembagaan Departemen Kesehatan Masyarakat Fakultas Ilmu Keolahragaan Universitas Negeri Semarang (No. 19444 / UN37.1.6 / TU / 2019). Instrumen yang digunakan dalam penelitian ini adalah kuesioner, kuesioner frekuensi makanan (FFQ), dan antropometri. Teknik pengumpulan data menggunakan observasi, pengukuran, dan wawancara. Teknik analisis data menggunakan univariat, bivariat, dan multivariat menggunakan software SPSS versi 16 for windows.

\section{HASIL DAN PEMBAHASAN}

Tabel 1. Distribusi Responden

\begin{tabular}{|c|c|c|c|}
\hline Karakteristik Responden & Deskripsi & $\begin{array}{c}\text { Frekuensi } \\
\quad \mathrm{N}=76\end{array}$ & $\begin{array}{c}\text { Presentase } \\
(\%)\end{array}$ \\
\hline \multirow[t]{2}{*}{ Riwayat Asupan Vitamin A } & Cukup & 51 & 67,1 \\
\hline & Tidak cukup & 25 & 32,9 \\
\hline \multirow[t]{2}{*}{ Riwayat Asupan Vitamin D } & Cukup & 60 & 78,9 \\
\hline & Tidak cukup & 26 & 21,1 \\
\hline \multirow[t]{2}{*}{ Kepatuhan Minum Obat } & Patuh & 50 & 65,8 \\
\hline & Tidak patuh & 26 & 34,2 \\
\hline \multirow[t]{2}{*}{ Kebiasaan Merokok } & Bukan Perokok & 53 & 69,7 \\
\hline & Perokok & 23 & 30,3 \\
\hline \multirow[t]{2}{*}{ Status Gizi } & Normal & 40 & 52,7 \\
\hline & Kurus & 36 & 47,3 \\
\hline \multirow[t]{2}{*}{ Usia } & 18-54 tahun & 56 & 73,7 \\
\hline & $>55$ tahun & 20 & 26,3 \\
\hline \multirow[t]{2}{*}{ Jenis Kelamin } & Laki-laki & 41 & 53,9 \\
\hline & Perempuan & 35 & 46,1 \\
\hline \multirow[t]{2}{*}{ Pekerjaan } & Bekerja & 45 & 59,2 \\
\hline & Tidak Bekerja & 31 & 40,8 \\
\hline \multirow[t]{2}{*}{ Tingkat Pendidikan } & Tinggi & 58 & 76,3 \\
\hline & Rendah & 18 & 23,7 \\
\hline
\end{tabular}




\section{Karakteristik Responden}

Dari tabel 1 terlihat bahwa responden yang memiliki riwayat asupan vitamin A cukup lebih banyak dibandingkan dengan responden yang tidak memiliki riwayat asupan vitamin A tidak cukup yaitu sebanyak $(67,1 \%)$. Responden yang memiliki riwayat asupan vitamin D cukup lebih banyak dibandingkan dengan responden yang tidak memiliki riwayat asupan vitamin D tidak cukup yaitu sebanyak (78,9\%). Responden yang patuh minum obat lebih banyak dibandingkan dengan responden yang tidak patuh minum obat yaitu sebanyak (65,8\%). Responden yang bukan perokok aktif lebih banyak dibandingkan dengan responden yang perokok aktif yaitu sebanyak $(69,7 \%)$. Responden yang memiliki status gizi normal lebih banyak dibandingkan dengan responden yang memiliki status gizi kurus yaitu sebanyak (52,7\%). Responden yang berusia 18-54 tahun lebih banyak dibandingkan dengan responden yang berusia> 55 tahun yaitu sebanyak $(73,7 \%)$. Responden dengan jenis kelamin laki-laki lebih banyak dibandingkan dengan responden jenis kelamin perempuan yaitu sebanyak $(53,9 \%)$. Responden yang bekerja lebih banyak dibandingkan dengan responden yang tidak bekerja yaitu sebanyak $(59,2 \%)$. Responden yang memiliki tingkat pendidikan tinggi lebih banyak dibandingkan dengan responden yang memiliki tingkat pendidikan rendah yaitu sebanyak $(76,3 \%)$.

\section{Bivariat}

Tabel 2. Analisis Bivariat

\begin{tabular}{|c|c|c|c|c|c|c|c|}
\hline \multirow{3}{*}{ Variabel } & \multicolumn{4}{|c|}{ Kesembuhan Tuberkulosis } & \multirow[t]{3}{*}{ Nilai p } & \multirow[t]{3}{*}{ OR } & \multirow[t]{3}{*}{$95 \% \mathrm{CI}$} \\
\hline & \multicolumn{2}{|c|}{ Konversi } & \multicolumn{2}{|c|}{ Tidak Konversi } & & & \\
\hline & $\mathbf{n}$ & $\%$ & $\mathbf{n}$ & $\%$ & & & \\
\hline \multicolumn{8}{|c|}{ Riwayat Asupan Vitamin A } \\
\hline Cukup & 32 & 84,2 & 19 & 50,0 & 0,002 & 5,333 & $1,813-15,692$ \\
\hline Tidak cukup & 6 & 15,8 & 19 & 50,0 & & & \\
\hline \multicolumn{8}{|c|}{ Riwayat Asupan Vitamin D } \\
\hline Cukup & 35 & 92,1 & 25 & 65,8 & 0.005 & 6,067 & $1,563-23,548$ \\
\hline Tidak cukup & 3 & 7,9 & 13 & 34,2 & & & \\
\hline \multicolumn{8}{|c|}{ Kepatuhan Minum Obat } \\
\hline Patuh & 32 & 84,2 & 18 & 47,4 & 0,001 & 5,926 & $2,013-17,445$ \\
\hline Tidak patuh & 6 & 15,8 & 20 & 52,6 & & & \\
\hline \multicolumn{8}{|l|}{ Kebiasaan Merokok } \\
\hline Bukan Perokok & 28 & 73,7 & 25 & 65,8 & 0,454 & 1,456 & $0,544-3,899$ \\
\hline Perokok & 10 & 26,3 & 13 & 34,2 & & & \\
\hline \multicolumn{8}{|l|}{ Status Gizi } \\
\hline Normal & 21 & 55,3 & 19 & 50,0 & 0,646 & 1,235 & $0,501-3,044$ \\
\hline Kurus & 17 & 44,7 & 19 & 50,0 & & & \\
\hline \multicolumn{8}{|l|}{ Usia } \\
\hline 18-54 tahun & 27 & 71,1 & 29 & 76,3 & 0,602 & 0,762 & $0,273-2,123$ \\
\hline$>55$ tahun & 11 & 28,9 & 9 & 23,7 & & & \\
\hline \multicolumn{8}{|l|}{ Jenis Kelamin } \\
\hline Laki-laki & 21 & 55,3 & 20 & 52,6 & 0,818 & 1,112 & $0,451-2,741$ \\
\hline Perempuan & 17 & 44,7 & 18 & 47,4 & & & \\
\hline \multicolumn{8}{|l|}{ Pekerjaan } \\
\hline Bekerja & 23 & 60,5 & 22 & 57,9 & 0,815 & 1,115 & $0,446-2,785$ \\
\hline Tidak Bekerja & 15 & 39,5 & 16 & 42,1 & & & \\
\hline \multicolumn{8}{|l|}{ Tingkat Pendidikan } \\
\hline Tinggi & 32 & 84,2 & 26 & 68,4 & 0,105 & 2,462 & $0,813-7,456$ \\
\hline Rendah & 6 & 15,8 & 12 & 31,6 & & & \\
\hline
\end{tabular}

Berdasarkan Tabel 2 dapat diketahui bahwa pada variabel riwayat asupan vitamin A, responden konversi dengan riwayat asupan vitamin A cukup sebanyak 32 orang $(84,2 \%)$ dan responden yang mempunyai riwayat asupan vitamin A tidak cukup sebanyak 6 orang $(15,8 \%)$. Sedangkan dari 38 responden tidak konversi dengan riwayat asupan vitamin A cukup sebanyak 19 orang (50,0\%) dan responden yang mempunyai riwayat asupan vitamin A tidak cukup sebanyak 19 orang (50,0\%). Hasil uji chi square menunjukan $p$ value sebesar 0,002 $(<0,05)$. Hasil analisis juga didapatkan nilai Odds Ratio (OR) bernilai 5,333 dengan 95\% CI=1,813-15,692 yang 
berarti bahwa responden yang memiliki riwayat asupan vitamin A cukup mempunyai peluang 5,333 kali untuk mengalami kesembuhan tuberkulosis daripada responden dengan riwayat asupan vitamin A tidak cukup.

Pada variabel riwayat asupan vitamin $\mathrm{D}$, responden konversi dengan riwayat asupan vitamin $\mathrm{D}$ cukup sebanyak 35 orang $(92,1 \%)$ dan responden yang mempunyai riwayat asupan vitamin D tidak cukup sebanyak 3 orang $(7,9 \%)$. Sedangkan dari 38 responden tidak konversi dengan riwayat asupan vitamin D cukup sebanyak 25 orang $(65,8 \%)$ dan responden yang mempunyai riwayat asupan vitamin D tidak cukup sebanyak 13 orang $(34,2 \%)$. Hasil uji chi square menunjukan $p$ value sebesar $0,005(<0,05)$. Hasil analisis juga didapatkan nilai Odds Ratio (OR) bernilai 6,067 dengan 95\% CI= 1,563-23,548 yang berarti bahwa responden yang memiliki riwayat asupan vitamin D cukup mempunyai peluang 6,067 kali untuk mengalami kesembuhan tuberkulosis daripada responden dengan riwayat asupan vitamin $\mathrm{D}$ tidak cukup.

Pada variabel kepatuhan minum obat, responden yang patuh minum obat sebanyak 32 orang $(84,2 \%)$ dan responden yang tidak patuh minum obat sebanyak 6 orang $(15,8 \%)$. Sedangkan dari 38 responden tidak konversi yang patuh minum obat sebanyak 18 orang $(47,4 \%)$ dan responden yang tidak patuh minum obat sebanyak 20 orang $(52,6 \%)$. Hasil uji chi square menunjukan $\mathrm{p}$ value sebesar $0,001(<0,05)$. Hasil analisis juga didapatkan nilai Odds Ratio (OR) bernilai 5,926 dengan 95\% CI= 2,013-17,445 yang berarti bahwa responden yang patuh minum obat mempunyai peluang 5,926 kali untuk mengalami kesembuhan tuberkulosis daripada responden yang tidak patuh minum obat.

Pada variabel kebiasaan merokok, responden konversi yang bukan perokok sebanyak 28 orang $(73,7 \%)$ dan responden yang perokok sebanyak 10 orang (26,3\%). Sedangkan dari 38 responden konversi yang bukan perokok sebanyak 25 orang $(65,8 \%)$ dan responden yang perokok sebanyak 13 orang $(34,2 \%)$. Hasil uji chisquare menunjukan $p$ value sebesar $0,454(>0,05)$. Hal ini berarti tidak ada hubungan antara kebiasaan merokok dengan kesembuhan Tuberkulosis. Hasil analisis juga didapatkan nilai Odds Ratio (OR) bernilai 1,456 dengan 95\% CI= 0,544-3,899.

Pada variabel status gizi, responden konversi yang memiliki status gizi normal sebanyak 21 orang $(55,3 \%)$ dan responden yang memiliki status gizi kurus sebanyak 17 orang $(44,7 \%)$. Sedangkan dari 38 responden tidak konversi yang memiliki status gizi normal sebanyak 19 orang $(50,0 \%)$ dan responden yang memiliki status gizi kurus sebanyak 19 orang (50,0\%). Hasil uji chi square menunjukan p value sebesar 0,646 (>0,05). Hal ini berarti tidak ada hubungan antara status gizi dengan kesembuhan Tuberkulosis. Hasil analisis juga didapatkan nilai Odds Ratio (OR) bernilai 1,235 dengan 95\% CI= 0,501-3,044.

Pada variabel usia, responden konversi yang memiliki usia 18-54 tahun sebanyak 27 orang $(71,1 \%)$ dan responden yang memiliki usia $>55$ tahun sebanyak 11 orang $(28,9 \%)$. Sedangkan dari 38 responden tidak konversi yang memiliki usia 18-54 tahun sebanyak 29 orang (76,3\%) dan responden yang memiliki usia > 55 tahun sebanyak 9 orang (23,7\%). Hasil uji chi square menunjukan $p$ value sebesar 0,602 $(>0,05)$. Hal ini berarti tidak ada hubungan antara usia dengan kesembuhan Tuberkulosis. Hasil analisis juga didapatkan nilai Odds Ratio (OR) bernilai 0,762 dengan 95\% CI=0,273-2,123.

Pada variabel jenis kelamin, responden konversi yang berjenis kelamin laki-laki sebanyak 21 orang $(55,3 \%)$ dan responden yang berjenis kelamin perempuan sebanyak 17 orang $(44,7 \%)$. Sedangkan dari 38 responden tidak konversi yang berjenis kelamin laki-laki sebanyak 20 orang $(52,6 \%)$ dan responden yang berjenis kelamin perempuan sebanyak 18 orang $(47,4 \%)$. Hasil uji chi square menunjukan $p$ value sebesar 0,818 (>0,05). Hal ini berarti tidak ada hubungan antara jenis kelamin dengan kesembuhan TB BTA Positif. Hasil analisis juga didapatkan nilai Odds Ratio (OR) bernilai 1,112 dengan 95\% CI= 0,451-2,741.

Pada variabel jenis pekerjaan, responden konversi yang bekerja sebanyak 23 orang $(60,5 \%)$ dan responden yang tidak bekerja sebanyak 15 orang (39,5\%). Sedangkan dari responden tidak konversi yang bekerja sebanyak 22 orang $(57,9 \%)$ dan responden yang tidak bekerja sebanyak 16 orang $(42,1 \%)$. Hasil uji chi square menunjukan p value sebesar 0,815 (>0,05). Hal ini berarti tidak ada hubungan antara pekerjaan dengan kesembuhan Tuberkulosis. Hasil analisis juga didapatkan nilai Odds Ratio (OR) bernilai 1,115 dengan $95 \% \mathrm{CI}=0,446-2,785$.

Pada variabel tingkat Pendidikan, responden konversi yang berpendidikan tinggi sebanyak 32 orang $(84,2 \%)$ dan responden yang berpendidikan rendah sebanyak 6 orang $(15,8 \%)$. Sedangkan dari responden tidak konversi yang berpendidikan tinggi sebanyak 26 orang $(68,4 \%)$ dan responden berpendidikan rendah sebanyak 12 orang $(31,6 \%)$. Hasil uji chi square menunjukan $\mathrm{p}$ value sebesar 0,105 $(>0,05)$. Hal ini berarti tidak ada hubungan antara tingkat pendidikan dengan kesembuhan Tuberkulosis. Hasil analisis juga didapatkan nilai Odds Ratio (OR) bernilai 2,462 dengan 95\% CI= 0,813-7,456.

Tabel 2 menunjukan bahwa variabel terkuat yang paling berpengaruh terhadap kesembuhan Tuberkulosis adalah kepatuhan minum obat. Hal ini dikarenakan variabel kepatuhan minum obat memiliki nilai $p$ paling kecil $(0,004)$ dan nilai Wald yang paling besar $(8,315)$ di antara variabel lain. Jadi secara berturut-turut yaitu kepatuhan minum obat $(8,315)$, riwayat asupan vitamin A $(6,956)$, dan riwayat asupan vitamin D $(4,547)$. 


\section{Multivariat}

Tabel 3. Analisis Multivariat

\begin{tabular}{cccccc}
\hline Variabel & B & Wald & $\begin{array}{c}\text { Nilai } \\
\mathbf{p}\end{array}$ & OR & 95\% CI \\
\hline $\begin{array}{c}\text { Riwayat Asupan } \\
\text { Vitamin A }\end{array}$ & 1,624 & 6,956 & 0,008 & 5,073 & $1,518-16,960$ \\
\hline $\begin{array}{c}\text { Riwayat Asupan } \\
\text { Vitamin D }\end{array}$ & 1,649 & 4,547 & 0,033 & 5,201 & $1,143-23,676$ \\
\hline $\begin{array}{c}\text { Kepatuhan } \\
\text { Minum Obat }\end{array}$ & 1,758 & 8,315 & 0,004 & 5,803 & $1,756-19,171$ \\
\hline
\end{tabular}

Berdasarkan tabel 3 dapat diketahui bahwa variabel terkuat yang paling berpengaruh terhadap kesembuhan tuberkulosis adalah kepatuhan minum obat. Hal ini dikarenakan variabel kepatuhan minum obat memiliki nilai $p$ paling kecil $(0,004)$ dan nilai Wald yang paling besar $(8,315)$ di antara variabel lain. Jadi secara berturut-turut yaitu kepatuhan minum obat $(8,315)$, riwayat asupan vitamin A $(6,956)$, dan riwayat asupan vitamin D (4,547). Berdasarkan hasil perhitungan probabilitas di atas, dapat disimpulkan bahwa penderita TB yang cukup asupan vitamin A dan D serta patuh minum obat memiliki probabilitas mengalami kesembuhan TB sebesar 79,6\%.

\section{Riwayat Asupan Vitamin A}

Hasil analisis pada penelitian ini didapatkan kesimpulan terdapat hubungan antara riwayat asupan vitamin A dengan kesembuhan Tuberkulosis. Hasil penelitian ini sesuai dengan penelitian yang dilakukan oleh Marpaung dkk (2018) menunjukan bahwa ada pengaruh suplementasi vitamin A pada pengobatan pasien TB Paru. Kekurangan vitamin A merupakan hal yang umum pada penderita TB.

Antioksidan berfungsi menetralisir radikal bebas dan menekan reaksi dari zat oksidatif sehingga dapat melindungi seseorang dari peradangan jaringan (Susilawati dkk, 2018). Vitamin A dalam kasus tuberkulosis memiliki peran yang penting dalam sistem imunitas dalam tubuh. Vitamin A juga memiliki peran sebagai sintesis protein yang banyak dibutuhkan dalam pertumbuhan tulang dan sel epitel. Asupan vitamin A yang cukup dapat menyebabkan penyembuhan tuberkulosis lebih cepat (Rahayu dkk, 2018).

Penelitian ini sejalan dengan penelitian yang dilakukan oleh Rita dkk (2016) yang menunjukan bahwa suplementasi memiliki pengaruh yang signifikan terhadap percepatan konversi pengobatan TB fase intensif, yakni setiap orang dalam kelompok perlakuan (diberi vitamin A dan D) memiliki peluang 2,45 kali lebih banyak untuk mengalami konversi dibandingkan dengan kelompok kontrol dengan perbandingan konstan untuk kedua kelompok. Responden kelompok perlakuan dengan konversi minggu ke-2 sebanyak 43\% dengan nilai BTA+ yang sama konversi kelompok perlakuan pada minggu ke 4.

\section{Riwayat Asupan Vitamin D}

Hasil analisis pada penelitian ini didapatkan kesimpulan terdapat hubungan antara riwayat asupan vitamin D dengan kesembuhan Tuberkulosis. Hasil penelitian ini mendukung hasil penelitian sebelumnya yang dilakukan oleh Sugiarti S, Ramadhian MR (2013) hasil penelitian menunjukan bahwa asupan vitamin $\mathrm{D}$ berpengaruh signifikan terhadap pasien yang sedang melakukan terapi kesembuhan TB. Vitamin D yang dikenal bermanfaat untuk tulang juga berfungsi sebagai imunomodulator yang terlibat dalam aktivasi makrofag melawan Mycobacterium tuberculosis. Penelitian sebelumnya menunjukan bagaimana mekanisme vitamin D dapat meningkatkan daya tahan tubuh melawan infeksi bakteri Mycobacterium tuberculosis. Vitamin D dapat meningkatkan sintesis dari komponen sistem imun bawaan melalui RVD (kompleks reseptor vitamin D) dengan bentuk aktif vitamin D yaitu 1,25D3; metabolit aktif, asam retinoid, dan 1, 25dihidroksivitamin D3 (1, 25 (OH) 2VD3) memiliki karakteristik sebagai hormon. Kedua metabolit aktif, yang disintesis dari vitamin prekursor, berada di jaringan tubuh yang berbeda dan sel dan bertujuan untuk mempengaruhi jarak sel target yang mengikat reseptor hormon. Salah satunya adalah cathelicidin yang mempunyai peran melawan infeksi Mycobacterium tuberculosis (Lubis dkk, 2017). Asupan vitamin D yang memadai dapat menurunkan resiko kambuh yang lebih rendah (Mehta et al., 2013). 


\section{Kepatuhan Minum Obat}

Hasil analisis pada penelitian ini didapatkan kesimpulan terdapat hubungan antara kepatuhan minum obat dengan kesembuhan Tuberkulosis. Kepatuhan minum obat adalah perilaku pasien untuk meminum obat sesuai dengan jenis, dosis, cara minum, waktu minum dan jumlah hari minum sesuai dengan pedoman penanggulangan TB. Pasien TB yang tidak menyelesaikan pengobatannya sampa tuntas maka beresiko terjadi restensi kuman TB terhadap obat TB semakin besar sehingga dapat terjadi kasus TB kebal obat atau TB MDR (Multy Drug Resistant) dan apabila orang lain juga tertular maka akan mengalami resistensi yang sama pula. Menurut penelitian yang dilakukan oleh Eka et al, (2010) menunjukan bahwa ada hubungan yang signifikan antara kepatuhan minum obat dengan hasil pengobatan (Eka et al., 2010). Hasil penelitian yang sama juga dilakukan oleh Niviasari dkk (2015) hasil penelitian menunjukan bahwa keteraturan pengobatan berhubungan dengan kesembuhan penderita TB Paru (Dhina Nurlita Niviasari et al., 2015). Hal ini sejalan dengan penelitian yang dilakukan oleh Widiyanto (2017) hasil penelitian menunjukan bahwa ada hubungan antara kepatuhan minum obat dengan pasien TB di Puskesmas Delangu Klaten. Penelitian yang sama juga dilakukan oleh (Suvianto and Hadiyanto, 2017) menunjukan bahwa kepatuhan minum obat berhubungan dengan kesembuhan pasien TB. Kesuksesan pengobatan TB saat ini masih rendah hal ini dikarenakan masih rendahnya kesadaran kepatuhan pasien TB dalam meminum obat anti TB (Agustina dkk, 2018). Pasien TB yang meminum obat secara teratur dapat menurunkan resiko 3,76 kali kegagalan pengobatan TB dibandingkan dengan pasien yang minum obat tidak teratur. Apabila pasien TB minum obat secara teratur misalnya dalam jangka waktu 2 minggu maka kuman TB sudah terpecah dan tidak berpotensi untuk menular. Jika kepatuhan minum obat tinggi maka kesembuhan Tuberkulosis juga akan meningkat sehingga resiko untuk terjadinya kasus TB resisten obat juga dapat dicegah (Widiyanto, 2017).

\section{Kebiasaan Merokok}

Hasil analisis pada penelitian ini didapatkan kesimpulan tidak terdapat hubungan antara kebiasaan merokok dengan kesembuhan Tuberkulosis. Penelitian ini sejalan dengan penelitian yang dilakukan oleh (Abal et al., 2005) Hal ini dapat terjadi karena hasil wawancara didapatkan bahwa kelompok kasus dan kontrol paling banyak adalah yang tidak memiliki kebiasaan merokok. Pada umumnya, kedua kelompok tersebut sama-sama telah mengetahui bahwa merokok dapat memperburuk fungsi paru-paru. Penurunan fungsi paru-paru menyebabkan parahnya penyakit tuberkulosis paru yang diderita. Jumlah responden yang merokok lebih sedikit dibandingkan dengan responden yang tidak merokok. Hal ini disebabkan responden yang telah diteliti pernah merokok dan setelah terkena tuberkulosis, responden tersebut berhenti dan tidak merokok kembali. Lalombo et al, (2015) dengan hasil penelitian menunjukan bahwa kebiasaan merokok justru berhubungan dengan kejadian TB Paru di Puskesmas Siloam Kecamatan Tamako Kabupaten Kepulauan Sangihe (Lalombo et al., 2015). Penelitian yang sama juga dilakukan oleh Setiarni dkk, (2013) hasil penelitian menunjukan bahwa ada hubungan antara kebiasaan merokok dengan kejadian TB Paru pada orang dewasa di Wilayah Kerja Puskesmas Tuan-Tuan Kabupaten Ketapang Kalimantan Barat (Setiarni, 2013). Dampak buruk rokok khususnya bagi kesehatan paru karena merokok tidak hanya berdampak pada perokok namun juga bagi orang lain yang ada dilingkungan tersebut yaitu perokok pasif. Asap rokok yang dihembuskan oleh perokok dan terhirup oleh perokok pasif lebih berbahaya dan mengandung 5 kali lebih banyak karbon monoksida dan 4 kali lebih banyak mengandung tar dan nikotin (Lalombo dkk, 2015). Indonesia menempati urutan ketiga pengkonsumsi rokok di dunia yaitu 28\% (65 juta penduduk Indonesia) atau 1 dari 4 penduduk. Badan Penelitian dan Pengembangan Kesehatan (Litbangkes) menunjukan bahwa mereka yang merokok (mereka yang masih merokok dan yang telah berhenti merokok) memiliki resiko menderita TB 3 kali lebih tinggi dibandingkan dengan mereka yang tidak merokok. Paparan dari tembakau baik yang secara aktif maupun pasif meningkatkan resiko terkena TB. Jika ada 1 perokok dalam satu rumah maka resiko terkena TB akan meningkat 9 kali lipat (Kementerian Kesehatan RI, 2013).

\section{Status Gizi}

Hasil analisis pada penelitian ini didapatkan kesimpulan tidak terdapat hubungan antara status gizi dengan kesembuhan Tuberkulosis. Penelitian ini sejalan dengan penelitian lain yang menunjukkan tidak ada hubungan status gizi dengan kesembuhan penderita tuberkulosis paru saat pengobatan tuberkulosis paru di Puskesmas Purwodadi Kabupaten Grobogan pada tahun 2010 (Murtantiningsih and Wahyono, 2010). Dalam keadaan normal, makin maju kemakmuran suatu negara makin sedikitlah rakyatnya yang terkena TB paru. Dengan menurunnya sistem imunitas, semua penyakit infeksi mudah sekali menyerang masuk TB Paru. Saat ini semua penderita TB secara teoritis harus dapat disembuhkan, asal saja yang bersangkutan rajin terus berobat sampai dinyatakan selesai, terkecuali bila dari awal TB yang dihadapi sudah resisten terhadap berbagai tuberkulostika. Status gizi yang baik merupakan salah satu faktor kesembuhan TB paru tetapi yang lebih berpengaruh adalah tingkat kepatuhan berobat (Cuevas et al, 2010). 
Penelitian ini tidak sejalan dengan penelitian yang dilakukan oleh Izah (2016) yang menunjukan bahwa status gizi berhubungan dengan kesembuhan TB Paru. Status gizi yang rendah secara signifikan berhubungan dengan tuberkulosis aktif dibandingkan dengan yang memiliki status gizi yang sehat (Izah, 2016). Terjadinya malnutrisi dapat menyebabkan defisiensi imun sekunder yang meningkatkan kerentanan inang terhadap infeksi. Salah satu faktor yang menyebabkan terjadinya TB paru adalah status gizi.

\section{Usia}

Hasil analisis pada penelitian ini didapatkan kesimpulan tidak terdapat hubungan antara usia dengan kesembuhan Tuberkulosis. Hal ini sejalan dengan penelitian yang dilakukan oleh Dotulong dkk (2015) menunjukan bahwa usia tidak berhubungan dengan kejadian TB Paru hal ini dikarenakan usia 15-55 tahun adalah kelompok usia yang mempunyai mobilitas yang tinggi sehingga kemungkinan terpapar kuman paru Mycrobakterum Tubekulosis paru lebih besar (Dotulong dkk., 2015). Penelitian yang dilakukan oleh (Kondoy et al, 2014) Prevalensi infeksi TB lebih sering terjadi pada usia yang lebih muda (Kondoy, P. P. H. et al., 2014). Hasil penelitian yang dilakukan oleh Maulidya dkk (2016) yang menunjukan bahwa tidak ada hubungan antara usia dengan keberhasilan pengobatan TB Paru di Puskemas Dinoyo (Maulidya dkk., 2016). Selanjutnya penelitian yang dilakukan oleh Diana (2014) menujukkan bahwa tidak ada hubungan antara usia dan keberhasilan pengobatan pasien TB (Diana, 2014). Penelitian yang sama juga dilakukan oleh (Suvianto and Hadiyanto, 2017) menunjukan bahwa usia tidak berhubungan dengan kesembuhan TB.

\section{Jenis Kelamin}

Hasil analisis pada penelitian ini didapatkan kesimpulan tidak terdapat hubungan antara jenis kelamin dengan kesembuhan Tuberkulosis. Penelitian ini sejalan dengan penelitian yang dilakukan oleh Nurkumalasari dkk (2016) yang menyebutkan bahwa jenis kelamin tidak berhubungan dengan kesembuhan TB Paru (Nurkumalasari dkk., 2016). Juga pada penelitian yang dilakukan oleh Agustina dkk (2018) yang menyebutkan bahwa jenis kelamin tidak memiliki hubungan yang signifikan dengan kesuksesan kesembuhan TB Paru (Agustina dkk., 2018). Menurut Sengul et al, (2012) tidak ada hubungan yang ditemukan antara jenis kelamin dan keberhasilan pengobatan dalam penelitian kami (Sengul et al., 2012). Orang yang lebih tua sering kali mengalami hal yang sama terhadap penyakit, kurang mampu menjangkau fasilitas kesehatan dan sedang lebih miskin dari populasi yang lebih muda (Cuevas et al, 2010).

Secara epidemiologi dibuktikan terdapat perbedaan antara laki-laki dan perempuan dalam hal penyakit, kejadian dan kematian akibat TB Paru. Penyakit TB Paru cenderung lebih tinggi pada jenis kelamin laki-laki dibandingkan perempuan, karena jenis kelamin laki-laki memiliki sifat keterpaparan dan tingkat kerentanan lebih tinggi daripada perempuan. Jenis kelamin laki-laki memiliki mobilitas yang tinggi seperti petani, sopir, tukang becak, tukang ojek dan pekerjaan berat lainnya yang memerlukan tenaga kuat dibandingkan perempuan yang hanya mengerjakan pekerjaan rumah tangga sehingga laki-laki memiliki kemungkinan lebih besar terpapar kuman TB (Iskandar, 2009)

\section{Pekerjaan}

Hasil analisis pada penelitian ini didapatkan kesimpulan tidak terdapat hubungan antara pekerjaan dengan kesembuhan Tuberkulosis. Penelitian ini tidak sejalan dengan penelitian yang dilakukan oleh Harnanik \& Ruhyana, (2014) yang menyebutkan bahwa ada hubungan antara pekerjaan dengan kesembuhan TB Paru (Harnanik \& Ruhyana, 2014). Pekerjaan merupakan sesuatu yang dilakukan untuk mencari nafkah dalam rangka untuk mencari kebutuhan ekonomi. Pekerjaan biasanya lebih banyak dilihat dari kemungkinannya terpapar TB serta ada risiko yang besar menurut sifat pekerjaannya. Faktor lingkungan kerja mempengaruhi seseorang untuk terpapar suatu penyakit dimana lingkungan yang buruk mendukung untuk terinfeksi TB Paru antara lain supir, buruh, tukang becak dan lain sebagainya dibandingkan dengan orang yang bekerja di perkantoran (Pane, 2012).

\section{Tingkat Pendidikan}

Hasil analisis pada penelitian ini didapatkan kesimpulan tidak terdapat hubungan antara pendidikan dengan kesembuhan Tuberkulosis. Penelitian ini sejalan dengan penelitian yang dilakukan oleh (Murtantiningsih and Wahyono, 2010) yang menyebutkan bahwa pendidikan tidak berhubungan dengan kesembuhan tuberkulosis. Penelitian ini sejalan dengan penelitian pada tahun 2013 di Istanbul, Turki, dan penelitian di Sharkia, Mesir, yang dilakukan oleh (Babalık et al 2013) (Elkomy et al, 2013) yang menyatakan bahwa tidak terdapat hubungan antara tingkat pendidikan dengan hasil pengobatan tuberkulosis. Tidak adanya hubungan dalam penelitian ini ditunjukkan dengan tingkat pendidikan terakhir pada masing-masing responden pada umumnya tidak berbeda dalam mendapatkan informasi pengobatan. Karena responden dengan tingkat pendidikan yang rendah pun bisa mendapatkan pengetahuan pengobatan melalui penyuluhan 
dari tenaga kesehatan. Berdasarkan penelitian ini tidak ada hubungan antara tingkat pendidikan dengan kejadian TB paru karena dalam penelitian ini diperoleh data bahwa sebagian besar tingkat pendidikan responden kasus dan kontrol masuk dalam kategori tingkat pendidikan tinggi $(84,2 \%)$. Hal ini berarti kesembuhan pasien Tb paru di wilayah kerja Puskesmas se-Kota Semarang dikarenakan faktor lain, bukan faktor tingkat pendidikan. Penelitian ini tidak sejalan dengan penelitian yang dilakukan oleh Puspitasari et al (2017) hasil penelitian menunjukan bahwa tingkat pendidikan berpengaruh terhadap kesembuhan TB Paru. (Puspitasari et al., 2017). Penelitian ini juga tidak sejalan dengan penelitian yang dilakukan oleh (Suvianto and Hadiyanto, 2017) yang menunjukan bahwa pendidikan berhubungan dengan kesembuhan TB.

\section{SIMPULAN}

Berdasarkan hasil penelitian yang dilakukan maka dapat disimpulkan bahwa faktor yang berhubungan dengan kesembuhan tuberkulosis pada penderita tuberkulosis di Kota Semarang adalah riwayat asupan vitamin A, riwayat asupan vitamin D, dan kepatuhan minum obat. Saran yang dapat diberikan kepada penderita TB diharapkan dapat meminum obat secara teratur sesuai dengan petunjuknya, didukung dengan asupan vitamin A dan D atau suplemen yang mengandung vitamin A dan D. Agar tidak terjadi kegagalan pengobatan yang berakibat pada resistensi dan sumber obat. Dalam penelitian selanjutnya diharapkan peneliti selanjutnya dapat melakukan penelitian lebih lanjut untuk memperdalam hasil penelitian ini dengan menggunakan desain yang berbeda. Peneliti memiliki keterbatasan pada variabel yang diteliti, tidak melakukan tes darah untuk mengetahui kadar vitamin D, dan kejujuran responden dalam menjawab pertanyaan wawancara. Sehingga peneliti harus melakukan pendekatan secara personal ketika mencari informasi yang dibutuhkan.

\section{DAFTAR PUSTAKA}

Abal, A. T. et al. (2005) 'Effect of cigarette smoking on sputum smear conversion in adults with active pulmonary tuberculosis', pp. 415-420. doi: 10.1016/j.rmed.2004.08.016.

Agustina, R., Maulida, R. and Yovsyah (2018) 'Faktor-Faktor yang Berhubungan dengan Kesuksesan Kesembuhan dari Pengobatan Regimen Pendek ( Short Treatment Regiment ) pada Pasien Tuberkulosis Resistensi Obat di Indonesia Tahun 2017 Factors Associated with Recovery Success after Short Treatment Regimen', Jurnal Epidemiologi Kesehatan Indonesia, 2(2), pp. 65-71.

Aibana, O. et al. (2019) 'Vitamin D status and risk of incident tuberculosis disease: A nested case-control study, sytematic review and individual participant data meta-analysis', PLoSMed, 16(9). doi: https://doi.org/10.1371/journal.pmed.1002907.

Babalık, A. et al. (2013) 'A Retrospective Case-Control Study, Factors Affecting Treatment Outcomes for Pulmonary Tuberculosis in İstanbul, Turkey’, pp. 204-210. doi: 10.5152/balkanmedj.2013.005.

Badan Penelitian dan Pengembangan Kesehatan Kementrian RI. (2013). Riset Kesehatan Dasar (RISKESDAS) 2013. Riskesdas 2013. https://doi.org/1 Desember 2013

Cuevas, L. E. et al. (2010) 'Factors associated with poor tuberculosis treatment outcome in the Southern Factors associated with poor tuberculosis treatment outcome in the Southern Region of Ethiopia', (August).

Dhina Nurlita Niviasari, Saraswati, L. D. and Martini (2015) 'Faktor-Faktor yang Berhubungan dengan Status Kesembuhan Penderita Tuberkulosis Paru', Jurnal Kesehatan Masyarakat (e-Journal), 3(3).

Diana, I. (2014) 'Hubungan Kepatuhan dan Sikap dengan Kepatuhan Berobat pada Pasien TB Paru yang Rawat Jalan di Jakarta Tahun 2014', Media Litbang, 26(4), pp. 243-248.

Dotulong, J. F. J., Sapulete, M. R. and Kandou, G. D. (2015) 'Hubungan Faktor Risiko Umur, Jenis Kelamin Dan Kepadatan Hunian Dengan Kejadian Penyakit Tb Paru Di Desa Wori Kecamatan Wori’, Jurnal 
Kedokteran Komunitas Dan Tropik, 3(2), pp. 57-65.

Eka, Y. et al. (2010) 'Hubungan Kepatuhan dalam Menjalani Pengobatan dengan Hasil Pengobatan pada Penderita Tuberkulosis Paru di BKPM Kota Semarang Periode Juli 2010 - Desember 2010 Relations ovfdn Medication Compliance with Treatment Outcomes in Patients with Pulmonary Tubercu', (2), pp. 51-54.

Elkomy, H. et al. (2013) 'Assessment of the efficacy of Directly Observed Treatment with short course ( DOTS ) for pulmonary tuberculosis in Sharkia governorate', Egyptian Journal of Chest Diseases and Tuberculosis. The Egyptian Society of Chest Diseases and Tuberculosis, 62(2), pp. 257-261. doi: 10.1016/j.ejcdt.2013.04.003.

G, J. et al. (2014) Vitamin D In Modern Nutrition in Health and Disease. 11th edn. Philadelphia: Lippincott Williams \& Wilkins.

Harnanik and Ruhyana (2014) Analisis Faktor-Faktor Yang Mempengaruhi Keberhasilan Pengobatan TB Paru di Puskesmas Purwodadi II Kabupaten Grobogan. Sekolah Tinggi Ilmu Kesehatan 'Aisyiyah Yogyakarta.

Iskandar (2009) Hubungan karakteristik penderita, lingkungan fisik, rumah dan wilayah dengan kejadian tuberkulosis paru di Kabupaten Aceh Tenggara tahun 2009. Universitas Sumatera Utara.

Izah, N. L. (2016) Hubungan Antara Status Gizi dengan Kesembuhan Pada Penderita Tuberkulosis Paru. UNISSULA.

Kementerian Kesehatan RI (2013) Fakta Seputar TB. Pengendalian Tuberkulosis di Indonesia. Jakarta.

Kementerian Kesehatan RI (2018) 'Infodatin Pusat Data dan Informasi', InfoDATIN 2018 Kementerian Kesehatan Republik Indonesia, p. 6. doi: 2442-7659.

Kondoy, P. P. H. et al. (2014) 'Factors related to compliance of tuberculosis lung patients in five public health centers in Manado City', Jurnal Kedokteran Komunitas dan Tropik, 2(1), pp. 1-8.

Lalombo, A., Palandeng, H. and Kallo, V. (2015) 'Hubungan Kebiasaan Merokok Dengan Kejadian Tuberkulosis Paru Di Puskesmas Siloam Kecamatan Tamako Kabupaten Kepulauan Sangihe’, Jurnal Keperawatan UNSRAT, 3(2), p. 107509.

Lubis, D. M. et al. (2017) 'Pengaruh Pemberian Vitamin D terhadap Gambaran Foto Toraks pada Pasien Tuberkulosis Paru Beretnis Batak', Global Medical \& Health Communication (GMHC), 5(1), p. 64. doi: 10.29313/gmhc.v5i1.2003.

Marpaung, A., Siagian, P. and Sari, D. K. (2018) 'Pengaruh Suplementasi Vitamin A pada Pengobatan Pasien TB Paru terhadap Percepatan Konversi Dahak pada Fase Intensif Di Wilayah Kerja Puskesmas Kecamatan Medan Kota', Jurnal Ilmu Kefarmasian Indonesia, 16(2), p. 124. doi: 10.35814/jifi.v16i2.512.

Maulidya, Y. N., Redjeki, E. S. and Fanani, E. (2016) 'Faktor yang Mempengaruhi Keberhsilan Pengobatan Tuberkulosis (TB) Paru Pada Pasien Pasca Pengobatan di Puskesmas Dinoyo'.

Mehta, S. et al. (2013) 'Vitamin D status and TB treatment outcomes in adult patients in Tanzania: a cohort study’, BMJ Open, 3(e003703). doi: doi:10.1136/bmjopen-2013-003703.

MR, B. (2010) Beta-Carotine Encyclopedia of Dietary Supplements. 2nd edn. London \& Newyork: Informa Healthcare. 
Murtantiningsih and Wahyono, B. (2010) 'Faktor-Faktor yang Berhubungan dengan Kesembuhan Penderita Tuberkulosis Paru', Jurnal Kesehatan Masyarakat, 6(1), pp. 44-50.

Nurkumalasari, Wahyuni, D. and Ningsih, N. (2016) 'Hubungan Karakteristik Penderita Tuberkulosis Paru dengan Hasil Pemeriksaan Dahak di Kabupaten Ogan Ilir', Jurnal Keperawatan Sriwijaya, 3(2).

Pane, I. L. (2012) 'Hubungan Antara Pekerjaan,PMO, Pelayanan Kesehatan, Dukungan Keluarga dan Diskriminasi dengan Perilaku Berobat Pasien TB Paru'.

Puspita, E., Christianto, E. and Indra, Y. (2013) 'Gambaran Status Gizi Pada Pasien Tuberkulosis Paru (Tb Paru) Yang Menjalani Rawat Jalan Di Rsud Arifin Achmad Pekanbaru', Journal of Chemical Information and Modeling, 53(9), pp. 1689-1699. doi: 10.1017/CBO9781107415324.004.

Puspitasari, Mudigdo, A. and Adriani, R. B. (2017) 'Effects of Education, Nutrition Status, Treatment Compliance, Family Income and Family Support on the Cure of Tuberculosis in Mojokerto, East Java', Journal Of Epidemiology and Public Health, 2(2), pp. 141-153.

Rahayu, R. F. (2018) ‘Asupan Protein , Vitamin a Dan Zink Dengan Status Gizi Pada Pasien Tuberkulosis’.

Sengul, A. et al. (2012) 'Original Article Factors affecting successful treatment outcomes in pulmonary tuberculosis: a single-center experience in Turkey , 2005 - 2011', pp. 2005-2011. doi: $10.3855 /$ jidc. 5925 .

Setiarni, S. M., Sutomo, A. H. and Hariyono, W. (2013) 'Hubungan Antara Tingkat Pengetahuan, Status Ekonomi Dan Kebiasaan Merokok Dengan Kejadian Tuberkulosis Paru Pada Orang Dewasa Di Wilayah Kerja Puskesmas Tuan-Tuan Kabupaten Ketapang Kalimantan Barat', Jurnal Kesehatan Masyarakat (Journal of Public Health), 5(3). doi: 10.12928/kesmas.v5i3.1072.

Sugiarti S, Ramadhian MR, C. N. (2013) 'Vitamin D sebagai suplemen dalam terapi tuberkulosis paru', Majority, 7(2), pp. 198-202.

Susilawati, M. D. et al. (2018) 'Asupan Gizi Makro Dan Mikro Penderita Tuberculosis Paru', Penelitian Gizi dan Makanan, 41(1), pp. 55-64.

Suvianto, C. A. and Hadiyanto (2017) 'Analysis of Factors Associated with the Healing Status of Pulmonary Tuberculosis Patients at Puskesmas Perumnas 1 Pontianak in 2018', Sriwijaya Journal of Medicine.

Widiyanto, A. (2017) 'Hubungan Kepatuhan Minum Obat Dengan Kesembuhan Pasien Tuberkulosis Paru BTA Positif Di Puskesmas Delanggu Kabupaten Klaten', Interest : Jurnal Ilmu Kesehatan, 6(1), pp. 7-12. doi: 10.37341/interest.v6i1.71. 